\title{
Editorial
}

\section{Despropósitos de una larga crisis}

El rico y sostenido recurso en mis alocuciones, diccionario de la Real Academia Española de La Lengua, ofrece numerosas acepciones sobre crisis y fácilmente sería capaz de argumentar con todas ellas, cobrando vida en relación con el otro término, menos vivaz, que he conjugado en el título de esta columna. De situación dificultosa a agónica en circunstancias; de momento decisivo y de graves consecuencias a posible cese; de expresión de carestía a sombra opaca a la que no se le ve salida.

El sinsentido de esta crisis que ya dura demasiado tiempo requiere de una alusión expresa a un tercer elemento, a los paganos de esta situación, a los damnificados, a los que han sufrido daño grave y, con su permiso, me volveré a referir con carácter colectivo solo a uno de ellos, a los más mayores de nuestra sociedad, y de soslayo a nosotros mismos.

La crisis — me pregunto — ¿ ¿ha podido ser la promotora de una devaluación de los valores? Cada vez tengo más dificultades para apreciar en estos días la perdurabilidad de algunos "principales" que otrora sostuvieron a una comunidad amenazada. La solidaridad con el prójimo, o más bien la falta de esta, mina una red tradicional y sólida, tejida con hebras orgullosas, capaces de soportar estrincones sociales y económicos. Hoy parece que solo el lazo familiar es responsable en exclusiva de esa obligación de "atender" a los más necesitados que antes compartía mayoritariamente toda una sociedad.

La crisis, no universal (los ricos siguen haciendo fortuna), ha hecho que muchas de nuestras familias hayan tenido que reorganizarse, tanto en el habitáculo como en las rentas a compartir. Casas de personas mayores, que deben acoger a hijos y nietos, ahora sin trabajo, sin hogar y muy a menudo sin ilusiones. Del rol de consolado que algunos veteranos esgrimían, al de sustento y consolador de los más cercanos que están viviendo situaciones crudas en sus planteamientos vitales. Se han vuelto a poblar casas vacías, con hijos y padres; hijos que abandonaron ese hogar hace años y padres que, quizá por esa falta de posibilidad de recibir los cuidados precisos en su casa, también pasaron a camas residenciales que ahora se ven vacías. "El abuelo vuelve a casa". "Nosotros lo cuidaremos". Lo no dicho: "con el coste de la residencia del abuelo trataremos de sobrevivir un poco más de tiempo".

La crisis ha dejado al descubierto la fina capa de barniz de una Ley de Dependencia, interesante, que ha tenido la mala fortuna de ver la luz en un momento inadecuado. Una gran conquista social, que vuelve a empañarse por falta de un desarrollo justo y suficiente que la posibilite más allá del papel. Numerosas familias ven cómo esas ayudas no llegan o, para aquellos que tuvieron mejor suerte, se cercenan día a día, frenando las aspiraciones de una atención global y de calidad para los más necesitados. El tiempo que se dieron las regiones para implementar este marco de derecho precisará al menos de una década más para reactivarse. Muchos ya no estarán aquí.

La crisis está tallando, con todas las aristas imaginables, desaliento y desabastecimiento. Las presiones laborales a las que, como en otros colectivos, se ha sometido a los profesionales sanitarios y sociales están traduciéndose a menudo en un desencanto que debilita la implicación e hipoteca la vocación, poniendo en peligro la calidad de los cuidados. La formación y la investigación en esta materia, ambos principios regeneradores de ilusión y mejora en la atención, ha quedado relegada cuando no suspendida por imperativo, a buen seguro por considerarlas poco relevantes y prescindibles. Plantillas más raquíticas y fatigadas en el ámbito gerontológico que solo pueden pensar en conservar sus puestos de trabajo, sin mirar a los lados o levantar la voz, porque están amenazados por la precariedad y la abrumadora oferta. Empezamos a ver cómo, especialmente en algunos centros residenciales (renglón seguido en domicilios y hospitales, no tengan du- 


\section{Editorial}

das), algunos productos básicos para la atención de los usuarios, como son los absorbentes (pañales) que brindaba el sistema sanitario público, han visto disminuida su provisión a la mitad. ¡Apenas dos pañales diarios para ancianos incontinentes! Los materiales para curas de heridas vuelven a ser aquellos trasnochados que fuimos abandonando hace más de dos décadas y el peso aplastante de las evidencias científicas disponibles y que avalan un uso coste-eficiente son sofocados por un credo exclusivo y erróneo al coste. Y...

Veremos cómo esta crisis, franca y activa todavía, se cobrará como nueva víctima, una reducción de la propia esperanza de vida que tanto lustre da o ha dado a nuestra ciudadanía. Habremos de esperar un poco para ver esa involución que demógrafos y gerontólogos vaticinan, pero ya podemos contemplar sin tener que separarnos un ápice de nuestro realidad cotidiana, un atentado contra la calidad de vida, tan vitoreada, un empobrecimiento radical de todos los grupos y el de los mayores doblemente si cabe (sus ahorros, ahora sostén de muchos, tocan fondo), una inestabilidad e inseguridad, para ellos y sus descendientes, que favorece la falta de ganas de vivir y una rabia contenida hacia los responsables de esta compleja situación (¿políticos, banqueros...?), que artefacta su salud en el más amplio sentido que esta palabra cobra en los mayores.

J. Javier Soldevilla Agreda Director de Gerokomos 